\title{
Analysis of The influence of The Medieval Pope During His Pontificate
}

\author{
Yini Wang* \\ College of Letters and Science, University of California, Berkeley, Berkeley, 94720, United State \\ cici.yini@gmail.com
}

\begin{abstract}
During the Middle Ages, people attached great importance to religion. Religion fully blends in with medieval life. Thus, religion acquired authority from people's dependence on religion. The pope is the supreme leader of the religion. What kind of position did the Pope have in medieval society through the influence of religion? Taking Pope Gregory II as an example, this article analyzes the position and role of the Pope in medieval life by understanding the experience of Gregory II during his pontificate. Gregory II is chosen as an example because he faced many religious, political, and military conflicts during his pontificate. According to the way of solving those conflicts, it can be seen that the influence of popes can have on medieval society. In the end, According to the analysis, it can be seen that the influence of the Pope not only existed in religion but also involved in politics and the military.
\end{abstract}

Keywords: Gregory II, Liber Pontificalis, iconolatry, Eighth Century Popes.

\section{INTRODUCTION}

The Middle Ages are also called the "Dark Ages" because the historical records of this period are relatively scarce. This article will first summarize Gregory II's experience during his pontificate and then analyze the purpose of his behavior. The understanding of the main experience of Gregory II is through the Lives of the Eighth Century Popes. Lives of the Eighth Century Popes is a book that is translated and organized from a large number of historical sources [1]. The analysis of his behavior also refers to the historical background and religious background at that time. This article focuses on the role of Pope Gregory II in medieval society. Although he cannot be a representation of all medieval popes, his experience provides some reference for people to understand the influence of popes in society at that time.

\section{CONTENT}

\subsection{Primary Sources of Information}

The understanding of the experience of Gregory II (Fig. 1) is based on pages 1-16 of a book called Lives of the Eighth Century. Lives of the Eighth Century Popes is a book that is translated and organized from a large number of historical sources [1.2]. The Book of Pontiffs is mainly cited on the pages I chose. The Book of Pontiffs is a book translated into English from the original Latin resource, Liber Pontificalis [3]. However, there is no complete English version of Liber Pontificalis. Liber Pontificalis is an ancient book of the papal chronicle that begins with Saint Peter and stops, incompletely, at the middle of the "Life of Stephen V" in 885. Because the book was in continual revision and the text was updated with each new Pope [4], specific authorship information about the Liber Pontificalis is difficult to confirm. Nevertheless, it is clear that the authors were of the same period as the material they recorded.

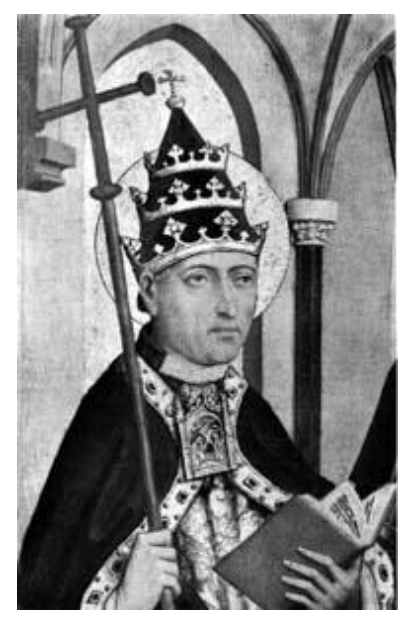

Fig. 1. Image of St. Gregory II 
The information shown in the book is that the writing of the information dating from S. Peter to Pope Damasus should have been done by Pope Damasus (Fig. 2). Because the preface to the book consists of two letters, one is a letter from Jerome to Pope Damasus asking him to compile a history from S. Peter to his own time (about the 4th century AD); The other one is a reply from Pope Damasus indicating that he agreed to the request [5]. Because Pope Damasus is a clergy, Popes' life recorded by a clergy is of a relatively higher credibility, like a paper written by an expert related to his profession. One theory held by some people is that Anastasius was the author [5]. Anastasius was a Roman church librarian and was proficient in Greek and Latin. This theory is controversial [6]. There is another theory by Edward Gibbon, who along with several other critics, Lucas Holftenius, Scheleftrate, Ciampini, Bianchini, and Muratori, claimed that the Liber Pontificalis was mainly written by the apostles and notaries of the 8th and 9th centuries and that Anaftafius wrote part of it [7].

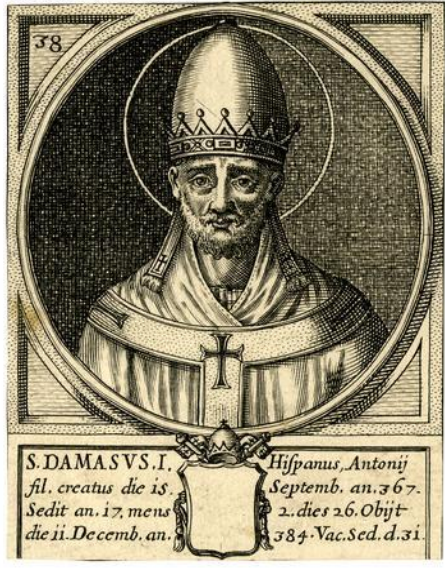

Fig. 2. Portrait of Pope Damasus I

All in all, one thing in common of these theories is that they all claim that the recorded of the Liber Pontificalis are basically clerics. In other words, the Popes' information were managed by the church itself. Meanwhile, the last theory indicated that perhaps notaries also participated in writing. Notaries belong to the government. If the authors of the Liber Pontificalis are clerics or notaries, their backgrounds can both demonstrate a degree of credibility. However, more detailed information about the author is still not available.

Another source that is cited a lot in the pages I chose is Scriptores and Scriptores Rerum Langobardicarum et Italicarum from Monumenta Germaniae Historica, Published by The Society for The Study of Older German History which founded in Frankfurt in 1819 [8]. It is a collection of manuscripts from all over Europe by printing and editing. This editing process continued into the 21 st century [9]. Although details about the authors of the original manuscripts have not been provided, a history organization that has been able to compile a historical document based on the original manuscripts should have a degree of credibility.

\subsection{Introduction of The Experience of Gregory II During His Pontificate}

The pontificate of Gregory II is from 715 to 731 . The reason he chose Gregory as his name was because he intended to pursue the reformist policies of Pope Gregory I [10].

At the start of his pontificate, Gregory II had issued a decree to restore the city's walls that commerced at $\mathrm{St}$ Laurence Cathedral's portico [2]. Except for this thing, Gregory II organized the reconstruction of various churches to make them usable again. He also established a monastery behind the apse of God's holy mother ad praesepe as the old people's home. However, there are no traces of the old people's house survive. The inference of old people's house is based on the oratory of that name built here by Symmachus at The Book of Pontiffs 53:9 [2]. And also, he instituted that on the Thursday in Lent there should be a liturgy and a celebration of mass in churches. This used not to occur [2].

Gregory II had contributed to the missionary work. An important close friend of Gregory II is Boniface (Fig. 3 ), who is an important Anglo-Saxon missionary with great influence among the Franks. Through bishop Boniface, he preached the message of salvation in Frankish kingdom. Although Gregory II planed to visit the north in person, it was never fulfilled. Missionary work was entrusted to bishop Boniface by Gregory II. They also kept frequent correspondence. Though this way, Gregory II converted many people to Christ [2].

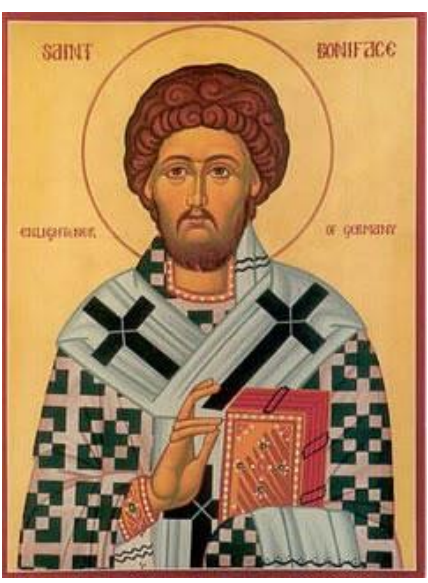

Fig. 3. Image of St. Boniface of Mainz

Gregory II had also contributed to politics. On his advice (and reproof), king Liutprand confirmed the restoration of the patrimony of the Cottian Alps and the Castellum of Sutri [2]. Gregory II also helped with the return of Castrum of Cumae. At that period, Lombards seized the Castrum of Cumae. Despite any suggestion even threat from Gregory II, Lombards refused to return 
the land. Thus, Gregory II devoted himself to writing letters to the Duke and the people of Naples to teach them how to rebel. In the end, they succeeded and got the land back [2].

Gregory II also have a conflict with the Byzantine emperor Leo III (Fig. 4), who ascended the throne in 717 [10]. Gregory II opposed the iconoclasm and tightened tax policy supported by Leo III [2]. The tightened tax policies was created because Leo III required more defense costs. Because the policy had a bad effect on the income of the church, Gregory II opposed the policy [2]. In 726, Leo III issued a decree declaring that it's illegal for people to use the images of saints. He equates the use of such representations of holy figures to the worship of pagan idols. In the opinion of Leo III, iconolatry is a desecration of the religion and the attack from Arabs on his empire is a punishment of iconolatry [11]. Gregory II, as an important leader of Christianity, opposed this decree and told Christians to ignore it. The Byzantine Exarchate of Ravenna also opposed this decree [10]. In the opinion of those who opposed this decree, the images of saints can help the illiterate people to understand the religion. And they did not lead people to believe that these artistic representations equal to real saints [11]. To summarize, economic and theological issues both led to a split of the imperial and theocratic power [2]. At that time, many people opposed the decree and supported the pontiff. They even wanted to replace Leo III. However, Gregory II restrained this plan as he hoped for Leo III's conversion [2]. The pontiff always tried to comfort the negative emotions of people and tried to stop them from doing anything rash [2]. He seems to prefer to solve problems in non-military ways, such as sincere persuasion. He indeed solved some of the problems that King Liutprand had with Rome or with him [2].

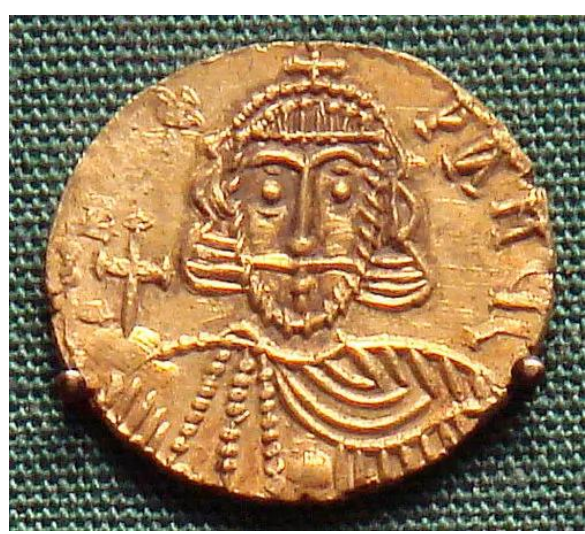

Fig. 4. Image of Leo III on the coin

\subsection{Analysis of The Experience of Gregory II During His Pontificate}

Lives of the Eighth Century Popes records the experience of Gregory II during his pontificate. Gregory II had contributed to both politics and religion during his pontificate. At the same time, he also provided help to people's lives. It's worth noting that during his pontificate, Gregory II not only restored the churches and carried out missionary work, but also restored the city wall of Rome. The former is very understandable, since he was the religious leader, but the latter was kind of mysterious - why did he carry out such a rebuilding project that seemed to have nothing to do with religion?

Gregory I (Fig. 5) wrote a book called The Book of Pastoral Rule. This Book records the standards of behaviors of spiritual directors based on the opinion of Gregory I. One of those standards is that

The spiritual director should not reduce his attention to The internal life because of external occupations, nor should he relinquish his care for external matters because of his anxiety for the internal life. Otherwise, he will either ruin his meditation because he is occupied by external concerns or else he will not give to his neighbors he owes to them because he has devoted himself to the inner life only [12].

The book also provides a detailed explanation of each standard. This standard indicates that spiritual directors should provide religious guidance to people as well as necessary help in life [12]. Meanwhile, Gregory II intented to pursue the reformist policies of Pope Gregory I. It is the reason for Gregory II chose Gregory as his name [10]. Although the city's wall had nothing to do with religion, the city's wall was very important to medieval people's life. People living in a safe environment can help them to focus more on praying and thinking about God. Therefore, Gregory II chose to restore the city's wall.

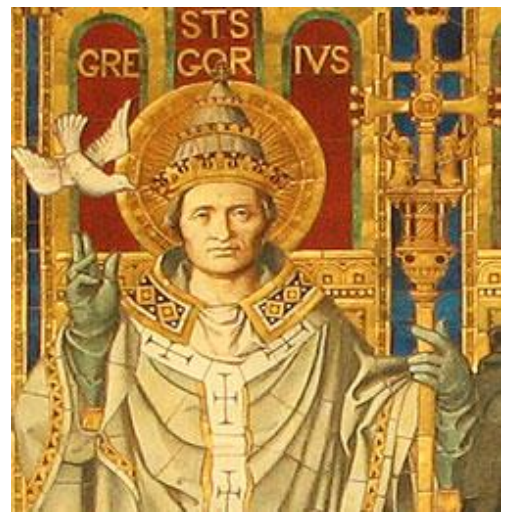

Fig. 5. Image of Pope St. Gregory the Great

This standard also indicates the political attitude of spiritual directors who believe in the book. This standard mentions that spiritual directors should pay attention to external matters as necessary but not too much. Because too much attention to external matters will reduce the attention to the internal life, and as a result it will not contribute to a firmer faith. Therefore, Gregory II would support the idea of a competent person to be emperor to deal with the external matters of the Byzantine empire. In this way, Gregory II could focus on religion and only deal 
with the necessary external matters, such as negotiating with the King of Lombards for the protection of national security to let them return Byzantine lands that had been invaded by them [2]. It also explains why Gregory II stopped the Ravenna army who supported him to attack Leo III [10] and the people's idea of replacing Leo III, even as he was openly enforcing the decree against iconolatry. Gregory II just hopes that Leo III will change his opinion [2]. However, this did not mean that Gregory II would tolerate the emperor. Gregory II had been opposed iconoclasm and tightened tax policy supported by Leo III. Gregory II's opposition may have been economic, but it was a political rebellion [2]. The opposition of iconoclasm was also a political rebellion.

However, according to Gregory II's beliefs, he is not a person who would oppose the existence of the emperor; according to the other things he did in politics, he had been protecting the Byzantine Empire. As a pontiff, even though Gregory II recognized his country, he always gave priority to religion. Thus, his opinions did not necessarily fit the actual condition of the empire. Similarly, as the Byzantine emperor, Leo III's opinions did not necessarily fit the religion. Therefore, the relationship between Gregory II and the Byzantine emperor is more like checks and balances. When there was no conflict, the pontiff and the Byzantine emperor can coexist with others; When there was a conflict, both of them would be made clear their position.

\section{CONCLUSION}

The importance of religion in medieval society can be analyzed by understanding the influence of a medieval pope. This article analyzes the purpose of Gregory II's behavior based on the historical and religious background and analyzes the position of Gregory II in medieval society according to the results. Although Gregory II is the only pope analyzed in this article, he represents how influential a pope can be in medieval society. This provides a reference for the study of medieval popes. If more medieval popes can be analyzed in the future, the understanding of medieval popes and medieval religions will become more accurate.

\section{REFERENCES}

[1]. Liverpool University Press. (2021) Books. https://www.liverpooluniversitypress.co.uk/books/i sbn/9781846311543/.

[2]. Davis, R. (1992) Gregory II. Lives of the EightCentury Popes. Liverpool University Press, Ann Arbor. pp. 1-16.

[3]. Google Book. (2000) The Book of Pontiffs (Liber Pontificalis).

https://books.google.com.hk/books?id=u7HMq57xl hsC\&amp;printsec=frontcover\&am $\mathrm{p} ; \mathrm{dq}=$ liber\%2Bpontificalis\&amp; $\mathrm{hl}=\mathrm{zh}$ CN\&amp;sa=X\&amp;redir_esc=y\&amp;sourceid= cndr\#v=onepage\&amp;q=liber\%20pontificalis\&am $\mathrm{p} ; \mathrm{f}=$ false.

[4]. Franklin, C. V. (2017) Reading the Popes: The Liber Pontificalis and Its Editors." Speculum 92, no. 3: 607-629. https://doi. org/10.1086/692789.

[5]. Lightfoot, J. B.. (1890) The Apostolic Fathers: A Revised Text with Introductions, Notes, Dissertations, and Translations, $2^{\text {nd }}$ Edition. Troon: Macmillan and Company, Troon.https://books.google.com.hk/books?id=ktkU AAAAYAAJ

$\& d q=$ Lightfoot, + Joseph+Barber.+1890.+The+Apos tolic+Fathers:+A+Revised+Text+with+Introductio ns,+Notes, + Dissertations, + and+Translations.+Mac millan. + p. $+311 \&$ hl=zh-

CN\&source=gbs_navlinks_s.

[6]. Herbermann, C. G. (1914) The Catholic Encyclopedia, Volume 16[Supplement]. In: Charles, G.H., Edward, A.P., Conde B.P., Thomas, J.S., John, J.W. (Eds.), Robert Appleton Company, New York. https://www.ccel.org/ccel/h/herbermann/cathen16/c ache/cathen 16. Pdf.

[7]. Gibbon, E. (1788) The History of The Decline and Fall of the Roman Empire, Volume The Fifth. Luke White,

Dublin. https://books.google.com.hk/books?id=xiw4Lq88S $\mathrm{AkC} \&$ printsec $=$ frontcover $\& \mathrm{dq}=$ Decline + and + Fall + of +the+Roman+Empire+1788\&hl=zh-

$\mathrm{CN} \& \mathrm{sa}=\mathrm{X} \&$ redir_esc $=\mathrm{y} \&$ sourceid $=\mathrm{cndr} \# \mathrm{v}=$ onepag e\&q=Decline $\% 20$ and $\% 20$ Fall $\% 20$ of $\% 20$ the $\% 20$ Ro man\%20Empire $\% 201788 \& \mathrm{f}=$ false.

[8]. Crane, S. A. (2018) Collecting and Historical Consciousness in Early Nineteenth Century Germany. Cornell Univ. Press, Ithaca. https://books.google.com. hk/books?id=ei5zDwAAQBAJ\&pg=PA83\&dq=Pre sidential+Address:+Great+Historical+Enterprises+I II.+The+Monumenta+Germaniae+Historica $\& \mathrm{hl}=\mathrm{zh}$

$\mathrm{CN} \& \mathrm{sa}=\mathrm{X} \&$ redir_esc $=\mathrm{y} \&$ sourceid $=\mathrm{cndr} \# \mathrm{v}=$ onepage $\& q=$ Presidential $\% 20$ Address $\% 3 \mathrm{~A} \% 20 \mathrm{Great} \% 20 \mathrm{Hi}$ storical\%20Enterprises\%20III.\%20The\%20Monum enta\%20Germaniae $\% 20$ Historica $\& \mathrm{f}=$ false.

[9]Cleaver, L. (2018) Illuminated History Books in the Anglo-Norman World, 1066-1272. Oxford University press, Oxford. https://books.google.com.hk /books?id=YBJbDwAAQBAJ\&pg=PA10\&dq=Pres idential+Address:+Great+Historical+Enterprises+II I. + The+Monumenta+Germaniae+Historica\&hl=zh- 
$\mathrm{CN} \& \mathrm{sa}=\mathrm{X} \&$ redir_esc $=\mathrm{y} \&$ sourceid $=\mathrm{cndr} \# \mathrm{v}=$ onepag e\&q=Presidential $\% 20$ Address $\% 3 \mathrm{~A} \% 20 \mathrm{Great} \% 20 \mathrm{H}$ istorical\%20Enterprises\%20III.\%20The\%20Monu menta\%20Germaniae $\% 20$ Historica\&f=false.

[10]Melton, J. G. (2014) Faiths across Time: 5,000 Years of Religious History. California:ABC-CLIO, California.https://books.google.com.hk/books?id=b I9_AwAAQBAJ\&dq=what+happened+in+Europe+ in $+715-731 \& \mathrm{hl}=\mathrm{zh}-\mathrm{CN} \&$ source=gbs_navlinks_s.

[11]The University of Utah. (2012) Icons and the Beginning Of the Isaurian Iconoclasm under Leo III. http://epubs.utah.edu/index.php/historia/article/dow nload/609/476.

[12]Pope Gregory I. (2007) The Book of Pastoral Rule. St Vladimir's Seminary Press, New York. https://books.google.com.hk/books?id=jbKkzWquz W sC\&dq=the + book+of + pastoral + rule $\& h l=z h-$ CN\&source $=$ gbs_navlinks_s. 